\title{
KULTIVASI MIKROALGA HIJAU PADA SUMBER NITROGEN BERBEDA UNTUK EKSTRAKSI LIPIDA
}

\author{
Irhamni, Elvitriana, Vera Viena* \\ Teknik Lingkungan Universitas Serambi Mekkah \\ Jl. Tgk Imum Lueng Bata Banda Aceh Telp 0651-0651-26160 / 0651-22471 \\ *e-mail: viena_violet@yahoo.com
}

\begin{abstract}
Abstrak
Mikroalga dikenal sebagai salah satu sumber utama penghasil bahan baku biodiesel untuk energy yang terbaharui karena kaya akan kandungan minyak. Penelitian ini mengkaji pengaruh Nitrogen dan metode ekstraksi terhadap kandungan lipida/minyak mikroalga hijau yang telah diaklimatisasi dalam limbah peternakan. Penelitian dilakukan dalam wadah kultivasi (fotobioreaktor) volume $2 \mathrm{~L}$ pada konsentrasi sumber Nitrogen berbeda $\left(0-0,4 \mathrm{~g} / \mathrm{L} \mathrm{KNO}_{3}\right)$. Selain itu juga diteliti keefektifan dua metode ekstraksi (Bligh - Dyer, dan Bligh - Dyer Modifikasi) untuk memperoleh minyak alga semaksimal mungkin. Hasil penelitian menunjukkan penambahan sumber Nitrogen yang berbeda pada kultivasi mikroalga yang telah di aklimatisasi memberikan kenaikan jumlah kandungan biomassa yang signifikan daripada yang tidak ditambahkan sumber nitrogen (kontrol). Sebaliknya kandungan lipid/minyak alga semakin menurun dengan tingginya kandungan sumber nitrogen dalam biomassa alga. Penggunaan dua metode ekstraksi berbeda tidak berpengaruh signifikan terhadap kandungan total lipida/minyak dari mikroalga. Hasil analisa GC-MS pada total lipida mikroalga menunjukkan komposisi terbesar berupa n-heksadecanoic acid (asam palmitat), octadecanoic acid (asam stearat) dan 9-(Z) octadecenoic acid (asam oleat), yang dapat berpotensi sebagai bahan baku biodiesel.
\end{abstract}

Kata Kunci: ekstraksi, kandungan lipida/minyak, mikroalga hijau, sumber Nitrogen,

Abstract

\begin{abstract}
Microalgae are known as one of the main sources of raw material producing biodiesel for renewable energy due to rich in oil content. This study examines the effect of nitrogen and extraction method on the content of lipid/oil green microalgae that has been acclimatized in livestock waste. The study was conducted in a container cultivation (photobioreactor) volume $2 \mathrm{~L}$ at concentrations of different nitrogen sources ( 0 to $\left.0.4 \mathrm{~g} / \mathrm{L} \mathrm{KNO}_{3}\right)$. It also examined the effectiveness of two methods of extraction (Bligh - Dyer, and Bligh - Dyer modification) to obtain algae oil as much as possible. The results showed the addition of different nitrogen sources on the cultivation of microalgae increased to a significant amount of
\end{abstract}

biomass content than those without added nitrogen source (control). The content of lipid/oil of algae decreased in regard with increased nitrogen source consentrations. The use of two different extraction methods are not significantly influence the content of total lipid / oil of microalgae. GC-MS analysis result showed the greatest compositions of microalgae lipid are n-heksadecanoic acid (palmitic acid), octadecanoic acid (stearic acid) and 9- (Z) octadecenoic acid (oleic acid), which can be potentially as a raw material for biodiesel.

Key words: extraction, green microalgae, lipid /oil content, nitrogen source 


\section{PENDAHULUAN}

Tingginya tingkat pencemaran lingkungan akibat penggunaan bahan bakar fosil telah mendorong sejumlah peneliti untuk menemukan bahan bakar ramah lingkungan yang berasal dari bahan baku minyak nabati. Menurut Meng dkk., (2009), biodiesel yang merupakan produk turunan dari minyak nabati merupakan material bahan bakar yang dapat diperbaharui, sehingga mempunyai potensi sebagai pengganti bahan bakar fosil. Upaya mencari sumber minyak nabati alternatif terus dilakukan dan pemanfaatan alga sebagai sumber minyak telah menarik perhatian peneliti akhir-akhir ini. Seperti tumbuhan lainnya, mikroalga juga dapat melakukan proces fotosintesis, namun dengan tingkat efisiensi yang lebih tinggi daripada tumbuhan darat lainnya. Produktivitas minyak yang dihasilkan oleh mikroalga jauh lebih besar daripada produksi terbaik dari tumbuhan penghasil minyak lainnya.

Mikroalga merupakan biomassa yang sangat efisien dalam mengambil bentuk limbah menjadi karbon (zero waste) dan mengubahnya menjadi bentuk energy cair berdensitas tinggi (minyak nabati) (Dote dkk., 1994).

Banyak penelitian telah dilakukan untuk menguji pertumbuhan mikroalga pada kondisi stress, dimana pada kondisi kekurangan nitrogen dalam medium, mikroalga akan mengakumulasi lipid (Evans dan Ratledge, 1984). Sheehan dkk., (1988) melaporkan bahwa meningkatnya kandungan lipid pada kondisi kekurangan nutrient disebabkan oleh laju produksi komponen sel yang rendah, tetapi produksi minyak tetap tinggi. Lingkungan stress seperti kurangnya nitrogen menyebabkan pembelahan sel terhambat, tetapi tidak memperlambat produksi minyak.

Berdasarkan latar belakang diatas, penelitian ini akan mengkaji pengaruh perbedaan konsentrasi sumber nitrogen dan metode ekstraksi minyak terhadap kandungan minyak dan komposisi asam lemak mikroalga hijau lokal Banda Aceh untuk mendapatkan kondisi pertumbuhan mikroalga optimal dengan kandungan minyak alga yang tinggi. Hasil yang diharapkan pada akhir penelitian ini adalah diperoleh metode ekstraksi terbaik untuk menghasilkan minyak nabati berkadar asam lemak tinggi yang berpotensi sebagai biodiesel.

FAME (Fatty acid methyl esters) yang berasal dari minyak sayuran dan lemak hewani dikenal sebagai biodiesel. Bahan bakar biodiesel telah banyak menarik perhatian dalam beberapa tahun terakhir, karena bersifat biodegradable, dapat diperbaharui dan tidak beracun. Biodiesel jenis ini tidak melepaskan $\mathrm{CO} 2$ dan sulfur ke atmosfer, dan menghasilkan polutan gas yang lebih sedikit daripada diesel normal.

Mikroalga mengandung lemak dan asam lemak sebagai komponen membran, produk simpanan, metabolit dan sumber energi. Komposisi kimia berbagai mikroalga diperlihatkan pada Tabel 2.1. Asam lemak dan minyak alga dipakai dalam banyak aplikasi. Minyak alga memiliki karakterisitik mirip dengan minyak nabati dan minyak ikan sehingga menjadi sumber alternatif pengganti produk-produk dari minyak fosil (Princen, 1982). Ekstraksi langsung minyak mikroalga merupakan cara yang lebih efisien untuk mendapatkan energi dari mikroorganisme dibandingkan fermentasi biomassa alga menjadi metana atau methanol. Kandungan minyak dan asam lemak mikroalga bervariasi menurut kondisi budidaya. Dalam beberapa kasus, kandungan minyak dapat ditingkatkan dengan proses kondisi kekurangan nitrogen atau fakctor stress lainnya.

Dalam pembuatan biodiesel beberapa variabel penting perlu dicermati, seperti jumlah mol alkohol (metanol/etanol), konsentrasi katalis $(\mathrm{KOH} / \mathrm{NaOH})$, suhu reaksi, dan waktu reaksi. Jumlah metanol optimum adalah $20 \%$, dengan konsentrasi $\mathrm{NaOH} 1 \%$, suhu reaksi $60^{\circ} \mathrm{C}$ dengan waktu reaksi 90 menit dengan kadar ester dalam biodiesel sebesar 98\%. Dalam pembuatan biodiesel biasanya minyak terlebih dahulu ditingkatkan kualitasnya (refining) dengan cara degumming dan netralisasi. Degumming dilakukan dengan cara menambahkan asam phosfat, sementara netralisasi dilakukan dengan 
menambahkan basa $\mathrm{NaOH}$. Minyak hasil netralisasi selanjutnya ditransesterifikasi dengan metanol atau etanol sebagai pereaksi.
Komposisi kimiawi beberapa alga dapat dilihat pada Tabel 1. Reaksi pembentukan senyawa alkil dapat dilihat pada Gambar 1 .

Tabel 1. Komposisi Kimiawi Beberapa Alga (\% Basis Kering)

\begin{tabular}{ccccc}
\hline Strain & Protein & Karbohidrat & Minyak & Asam Nukleat \\
\hline Scenedesmus obliquus & $50-56$ & $10-17$ & $12-14$ & $3-6$ \\
Scenedesmus dimorphus & $8-18$ & $21-52$ & $16-40$ & - \\
Chlamydomonas rheinhardii & 48 & 17 & 21 & - \\
Chlorella vulgaris & $51-58$ & $12-17$ & $14-22$ & $4-5$ \\
Spirogyra sp. & $6-20$ & $33-64$ & $11-21$ & - \\
Euglena gracilis & $39-61$ & $14-18$ & $14-20$ & - \\
Prymnesium parvum & $28-45$ & $25-33$ & $22-38$ & $1-2$ \\
Porphyridium cruentum & $28-39$ & $40-57$ & $9-14$ & - \\
Syncchoccus s. $^{\wedge}$ & 63 & 15 & 11 & 5 \\
\hline
\end{tabular}

Sumber: Becker (1994).

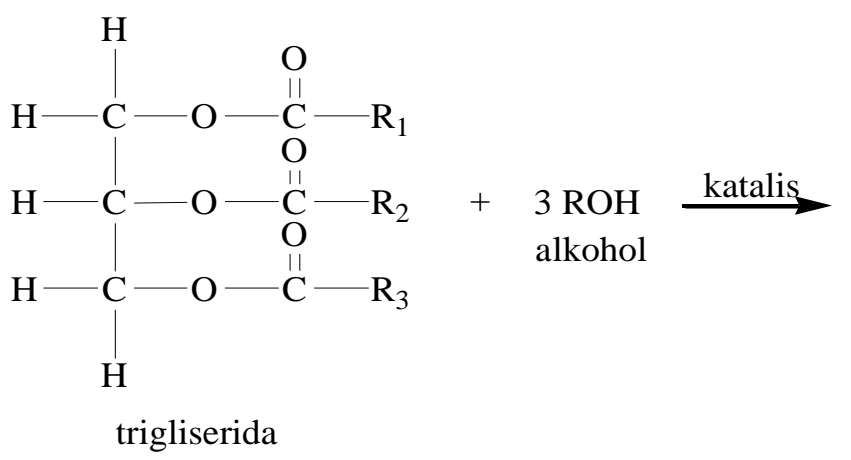<smiles></smiles>

Gambar 1. Reaksi pembentukan senyawa alkil ester (biodiesel)

\section{METODA}

Penelitian ini bersifat eksperimental murni dan diarahkan agar setelah selesai penelitian, kondisi optimum untuk produksi minyak alga oleh mikroalga hijau hasil aklimatisasi dapat diperoleh. Perlakuan penelitian adalah:

(1)Variabel tetap: Intensitas cahaya (lampu fluorescent dari photobioreaktor): $4 \times 8$ Watt; waktu kultivasi 14 hari, siklus pencahayaan kontinyu 24 jam.

(2) Variabel bebas: Aklimatisasi mikroalga dalam konsentrasi Nitrogen berbeda (sumber KNO3 dari $0 \mathrm{~g} / \mathrm{L} ; 0,05 \mathrm{~g} / \mathrm{L} ; 0,1$ $\mathrm{g} / \mathrm{L} ; 0,2 \mathrm{~g} / \mathrm{L} ; 0,3 \mathrm{~g} / \mathrm{L} ; 0,4 \mathrm{~g} / \mathrm{L}$ ); Metode ekstraksi minyak Bligh - Dyer, dan Bligh - Dyer Modifikasi.

\section{HASIL DAN PEMBAHASAN}

Pada penelitian sebelumnya telah diperoleh mikroalga terbaik hasil aklimatisasi didalam limbah peternakan dengan konsentrasi limbah sebagai media pertumbuhan alternatif sebanyak $25 \%$ v/v. Mikroalga teraklimatisasi ini digunakan sebagai strain utama untuk penelitian lanjutan ini dengan diberikan perlakuan tambahan sumber Nitrogen yang berbeda dalam kisaran $(0,05 \mathrm{~g} / \mathrm{L}-0,4$ g.L $)$. Pertumbuhan mikroalga dalam bentuk kurva kandungan biomassa kering mikroalga ditunjukkan pada gambar berikut ini. Disimpulkan bahwa mikroalga teraklimatisasi dapat tumbuh dengan baik pada kondisi sumber nitrogen berbeda. Semakin tinggi tingkat 
penambahan nitrogen dalam bentuk KNO3 maka kandungan biomassa semakin tinggi. Hal ini diharapkan berbanding lurus dengan kandungan lipid yang terkandung didalam biomassa. Sheehan dkk., (1988) melaporkan bahwa meningkatnya kandungan lipid pada kondisi kekurangan nutrient disebabkan oleh laju produksi komponen sel yang rendah, tetapi produksi minyak tetap tinggi. Lingkungan stress seperti kurangnya nitrogen menyebabkan pembelahan sel terhambat, tetapi tidak memperlambat produksi minyak.

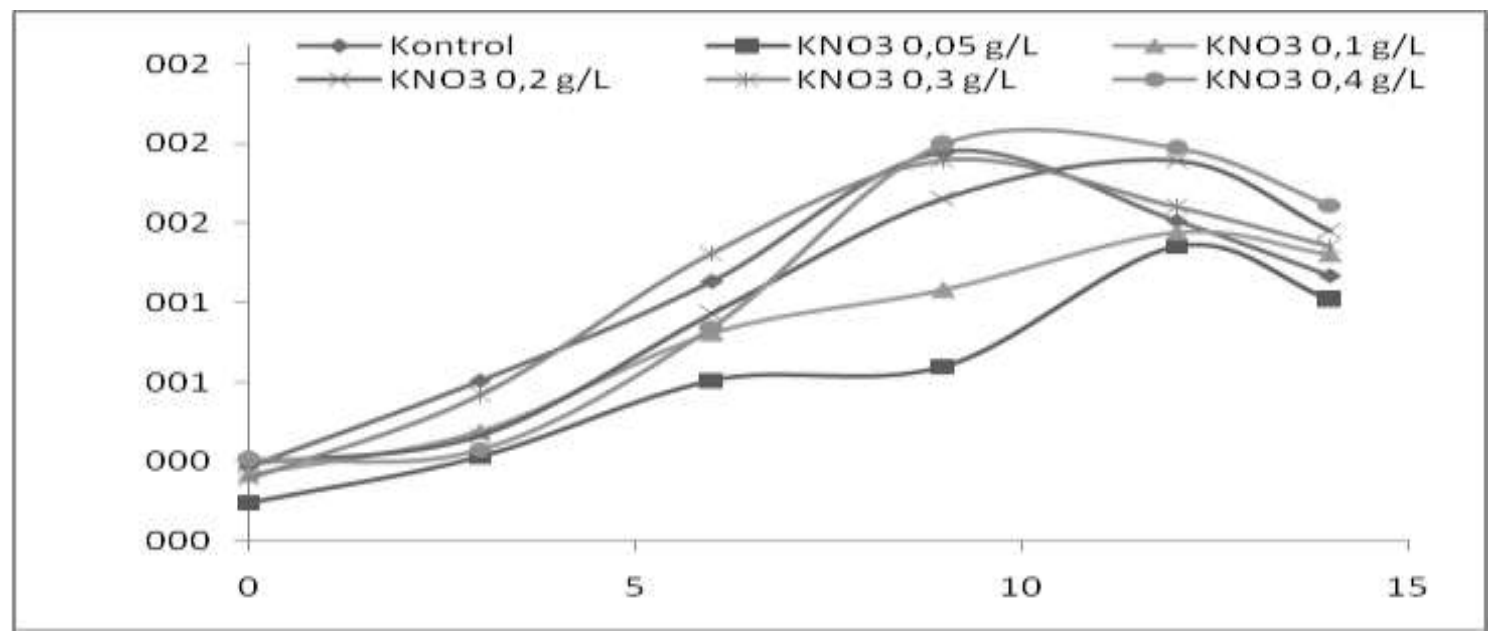

Gambar 2. Kurva pertumbuhan mikroalga hasil aklimatisasi pada kondisi sumber Nitrogen berbeda

Hasil penelitian menunjukkan bahwa penambahan sumber Nitrogen yang berbeda pada kultivasi mikroalga yang telah di aklimatisasi menunjukkan kenaikan jumlah kandungan biomassa yang signifikan daripada yang tidak ditambahkan sumber Nitrogen (kontrol). Tetapi sebaliknya kandungan lipid/minyak alga semakin menurun dengan tingginya kandungan sumber Nitrogen dalam biomassa alga. Hal ini disebabkan oleh penyerapan Nitrogen yang tinggi oleh klorofil mikroalga hijau sehingga menutupi lapisan lipid pada dinding sel mikroalga.

\section{Pengaruh Metode Ekstraksi terhadap Kandungan Lipida Mikroalga.}

Ekstraksi langsung minyak mikroalga merupakan cara yang lebih efisien untuk mendapatkan energi dari mikroorganisme dibandingkan fermentasi biomassa alga menjadi metana atau methanol. Kandungan minyak dan asam lemak mikroalga bervariasi menurut kondisi budidaya. Dalam beberapa kasus, kandungan minyak dapat ditingkatkan dengan proses kondisi kekurangan nitrogen atau faktor stress lainnya. Kandungan minyak mikroalga dapat mencapai $70-85 \%$ berat kering. Kondisi pertumbuhan, tahap pertumbuhan budidaya dan posisi taksonomi alga memberikan pengaruh terhadap kandungan dan jenis lemak. Pada tahap awal pertumbuhan alga, alga biru menghasilkan lemak polar dan asam lemak tak jenuh ganda $\boldsymbol{C}_{16}$ dan $\mathrm{C}_{18}$ dalam jumlah besar. Pada saat mendekati fasa pertumbuhan stasioner, lemak netral dominan dihasilkan dan umumnya terdiri dari asam lemak jenuh 18:1 dan 16:0. Dalam hal alga biru-hijau, komposisi lemak dan asam lemak memperlihatkan sedikit perubahan selama siklus pertumbuhan. Kandungan dan komposisi minyak dan asam lemak juga dipengaruhi oleh beberapa faktor lain. Cahaya meningkatkan pembentukan lemak tak jenuh ganda asam lemak $\boldsymbol{C}_{\boldsymbol{1 6}}$ dan $\mathrm{C}_{18}$, dan juga mono dan di-galaktosil-digliserida, spingolipida dan fosfogliserida didalam Euglena gracils dan Chlorella vulgaris. 


\section{Ekstraksi Metode Bligh-Dyer}

Metode dasar analisis ini merupakan modifikasi dari Bligh dan Dyer (1959). Sel alga yang dipanen dihancurkan dengan mortar dan dipindahkan kedalam corong pemisah. Lipid diekstraksi dengan larutan kloroform metanol $(2: 1, \mathrm{v} / \mathrm{v})$ dan terpisah menjadi lapisan cairan kloroform dan metanol dengan penambahan metanol dan air untuk menghasilkan rasio pelarut akhir dari kloroform : metanol : air sebesar 1:1:0.9. Lapisan kloroform dicuci dengan $20 \mathrm{ml}$ larutan $\mathrm{NaCl} 5 \%$, dan diuapkan sampai kering, total lipid ditentukan secara gravimetric. Hasil kandungan yield lipid mikroalga menggunakan metode Bligh Dyer dapat dilihat pada Tabel 1.

Pada penelitian ini diperoleh hasil bahwa semakin tinggi penambahan sumber Nitrogen pada masa kultivasi dapat meningkatkan kandungan biomassa mikroalga, tetapi sebaliknya menurunkan kandungan lipid mikroalga. Ekstraksi lipid dengan biomassa basah lebih baik daripada biomassa kering, hal ini disebabkan oleh proses penghancuran awal daripada biomassa kering mikroalga yang hanya menggunakan mortar sederhana sehingga hasil lipid yang diperoleh tidak maksimum.

Penggunaan biomassa alga basah menunjukkan hasil lipid yang lebih menjanjikan dimana, dengan penghancuran biomassa dengan mortar telah dapat merusak jaringan dinding sel mikroalga sehingga dapat diperoleh lipid yang lebih optimal. Pembentukan lipid mikroalga juga sangat ditentukan oleh kondisi pertumbuhan mikroalga, dimana penggunaan aerasi karbondioksida menunjukkan kandungan lipid yang lebih baik daripada aerasi dengan udara. Selain itu juga perlu diperhatikan perbandingan pelarut akhir yang digunakan untuk mengekstrak lipid mikroalga (perbandingan kloroform/methanol/air) secara lebih baik.

\section{Ekstraksi Metode Bligh- Dyer Modifikasi}

Proses ektraksi dengan metode Bligh Dyer Modifikasi membutuhkan ketelitian yang nyata agar diperoleh lipid yang optimum, dimana beberapa kali proses pengulangan penambahan pelarut lemak/lipid dapat membantu ekstraksi semua lipid yang terkandung dalam biomassa basah maupun kering. Modifikasi yang dimaksudkan disini adalah modifikasi perbandingan perlarut lipid yang ditambahkan bervariasi, sehingga dapat diperoleh lipid yang lebih banyak untuk bahan baku biodiesel. Hasil yield minyak alga dapat dilihat pada Tabel 1 .

Yield kandungan lipid/minyak dan asam lemak hasil ekstraksi Bligh-dyer dan Bligh-dyer Modifikasi menunjukkan bahwa kedua metode ini lebih efektif digunakan untuk biomassa basah, dimana proses pemanenan dan penghancuran sel-sel biomassa alga basah sangat berpengaruh pada pelepasan lipida/minyak yang terkandung pada biomassa mikroalga. Sedangkan ekstraksi lipid pada biomassa kering butuh waktu yang lebih lama untuk dapat memecahkan lapisan sel kering. Hasil analisa GC-MS pada total lipid alga menunjukkan kandungan n-heksadecanoic acid (asam palmitat), octadecanoic acid (asam stearat) dan 9-(Z) octadecenoic acid (asam oleat), yang dapat berpotensi sebagai bahan baku biodiesel. 
Tabel 1. Data Kandungan minyak/lipid pada biomassa mikroalga

\begin{tabular}{|c|c|c|c|c|c|c|c|c|c|c|c|c|}
\hline \multirow{2}{*}{$\begin{array}{c}\text { Metode } \\
\text { Ekstraksi }\end{array}$} & \multicolumn{2}{|c|}{ kontrol } & \multicolumn{2}{|c|}{$\mathbf{0 , 0 5}$ KNO3 } & \multicolumn{2}{|c|}{0,1 KNO3 } & \multicolumn{2}{|c|}{0,2 KNO3 } & \multicolumn{2}{|c|}{0,3 KNO3 } & \multicolumn{2}{|c|}{0,4 KNO3 } \\
\hline & BK & BB & BK & BB & BK & BB & BK & BB & BK & BB & BK & BB \\
\hline Bligh-Dyer & ND & 0,71 & ND & 0,98 & 0,7 & 0,65 & 0,64 & 0,72 & 0,58 & 0,67 & 0,5 & 0,56 \\
\hline $\begin{array}{l}\text { Bligh-Dyer } \\
\text { Modifikasi }\end{array}$ & 1,12 & 1,37 & 1,27 & 1,42 & 1,18 & 1,3 & 0,86 & 1,14 & 0,75 & 0,97 & 0,64 & 0,85 \\
\hline
\end{tabular}

\section{Analisa Kandungan Lipid dan Asam Lemak Mikroalga dengan GC-MS}

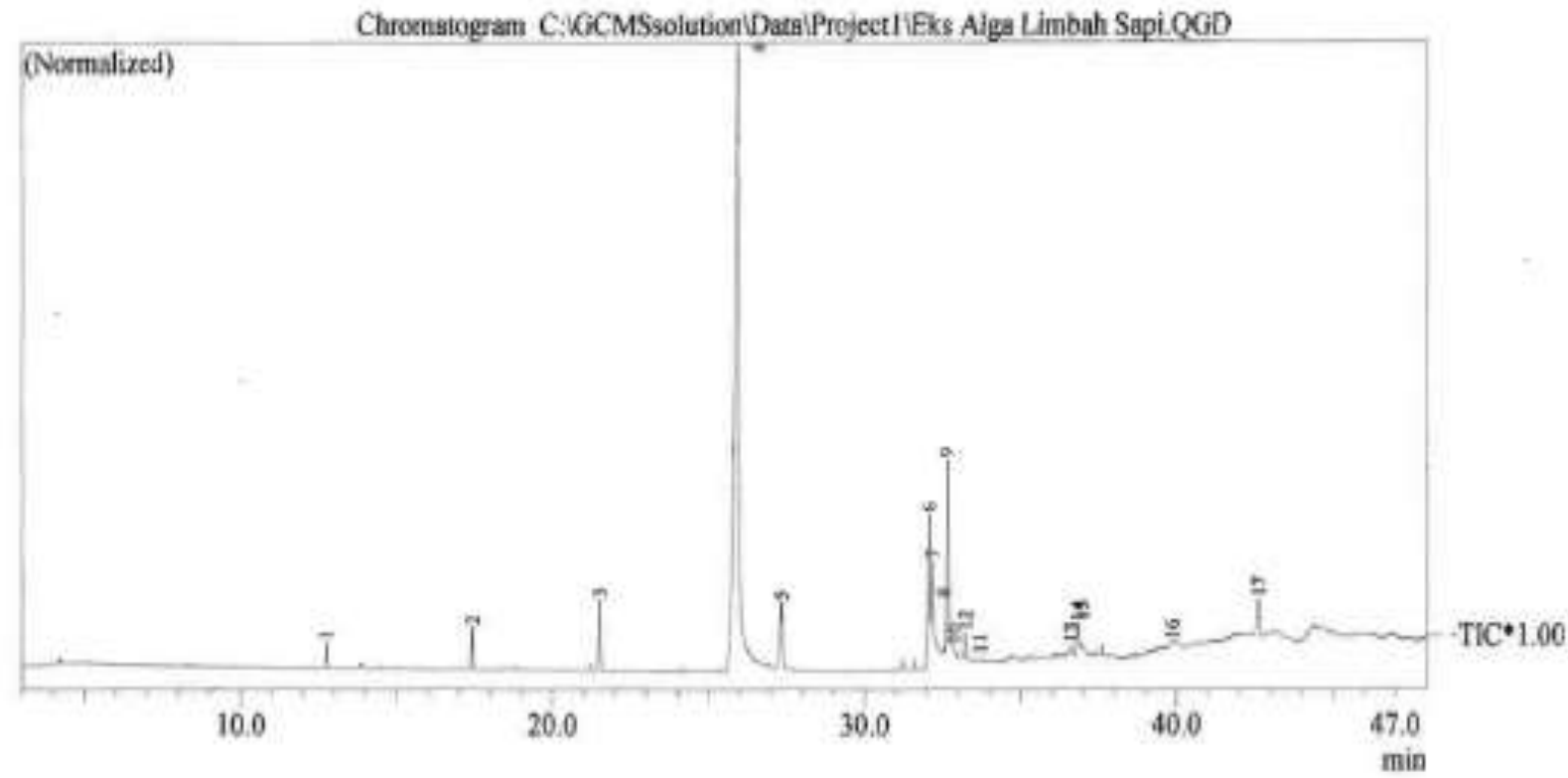

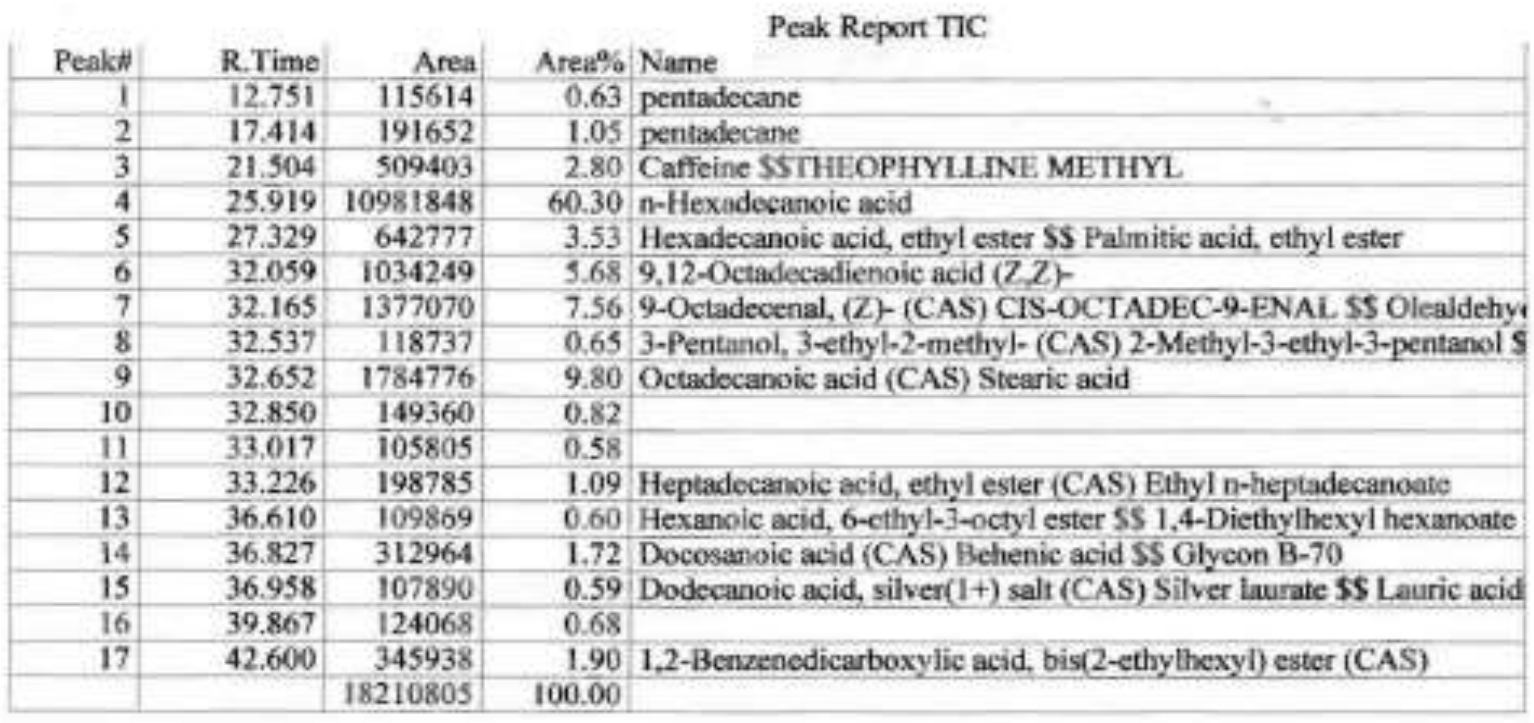




\section{KESIMPULAN DAN SARAN}

\section{Kesimpulan}

Mikroalga yang telah diaklimatisasi dapat tumbuh dengan baik pada kondisi sumber nitrogen berbeda dengan kandungan biomassa tertinggi diperoleh pada sumber Nitrogen 0,4 $\mathrm{g} / \mathrm{L}$ dengan kandungan biomassa kering mencapai $1,9 \mathrm{~g} / \mathrm{L}$.

Semakin tinggi sumber nitrogen dalam biomassa sebaliknya semakin menurunkan kandungan lipid dalam biomassa. Yield kandungan lipid/minyak dan asam lemak hasil ekstraksi Bligh-dyer dan Bligh-dyer Modifikasi menunjukkan bahwa kedua metode ini lebih efektif digunakan untuk biomassa basah, dimana proses pemanenan dan penghancuran sel-sel biomassa alga sangat berpengaruh pada pelepasan lipida/minyak yang terkandung pada biomassa mikroalga.

Hasil analisa GC-MS pada total lipid alga menunjukkan kandungan n-heksadecanoic acid (asam palmitat), octadecanoic acid (asam stearat) dan 9-(Z) octadecenoic acid (asam oleat), yang dapat berpotensi sebagai bahan baku biodiesel.

\section{Ucapan Terima Kasih}

Ucapan terima kasih kami yang sebesarnya kepada DIPA Kopertis Wilayah I yang telah sepenuhnya membiayai penelitian ini.

\section{DAFTAR PUSTAKA}

Becker, E.W., 1994, Microalgae: Biotechnology and Microbiology, Ed. Baddiley, J. et al, 178 Cambridge Univ. Press, Cambridge, New York.

Chisty, Y., 2007, Biodiesel from Microalgae, Biotechnology Advances : 25 : 293-306

Dote, Y., S. Sawayama, S. Inoue, T. Minowa, and S. Yokoyama, 1994, Recovery of Liquid Fuel from Hydrocarbon-Rich Microalgae by Thermochemical Liquefaction, J. Fuel, Vol 73, 1855.
Evans, C. T. and C. Ratledge, 1984, Effect of Nitrogen Source on Lipid Accumulation Oleaginous Yeasts, J. Gen. Microbiol., Vol 130, 1693.

Meng, X., Yang, J., Xu, X., Xhang, L., Nie, Q. dan Xian, M. 2009, Biodiesel production from oleaginous microorganism, $J$. Renewable Energy, vol.34, hal.i-5.

Princen, L.H., 1982, Economic Botany, Vol 36, 302-312.

Sheehan, J., Dnahay, T., Benemann, J. dan Roessler, P., 1998, A Look Back at the US Department of Energy's Aquatic Species Program - Biodiesel from Algae, US DEO of Fuels Development.

Teresa M. M., Antonio A. M. dan Caetano, N.S. 2010, Microalgae for Biodiesel Production and Other Applications: A Review, Renewable and Sustainable Energy, 14 217-23

Werner, D., Lewin \& Guilard, 1966, Archiv fur Mikrobiclogie, 55, 278-308 